\title{
Retinal microvascular diameters
}

Citation for published version (APA):

Houben, A. J. H. M., Berendschot, T. T. J. M., \& Grassi, G. (2017). Retinal microvascular diameters: normative data and their use in clinical hypertension. Journal of Hypertension, 35(8), 1573-1574. https://doi.org/10.1097/HJH.0000000000001421

Document status and date:

Published: 01/08/2017

DOI:

10.1097/HJH.0000000000001421

Document Version:

Publisher's PDF, also known as Version of record

Document license:

Taverne

Please check the document version of this publication:

- A submitted manuscript is the version of the article upon submission and before peer-review. There can be important differences between the submitted version and the official published version of record.

People interested in the research are advised to contact the author for the final version of the publication, or visit the DOI to the publisher's website.

- The final author version and the galley proof are versions of the publication after peer review.

- The final published version features the final layout of the paper including the volume, issue and page numbers.

Link to publication

\footnotetext{
General rights rights.

- You may freely distribute the URL identifying the publication in the public portal. please follow below link for the End User Agreement:

www.umlib.nl/taverne-license

Take down policy

If you believe that this document breaches copyright please contact us at:

repository@maastrichtuniversity.nl

providing details and we will investigate your claim.
}

Copyright and moral rights for the publications made accessible in the public portal are retained by the authors and/or other copyright owners and it is a condition of accessing publications that users recognise and abide by the legal requirements associated with these

- Users may download and print one copy of any publication from the public portal for the purpose of private study or research.

- You may not further distribute the material or use it for any profit-making activity or commercial gain

If the publication is distributed under the terms of Article $25 \mathrm{fa}$ of the Dutch Copyright Act, indicated by the "Taverne" license above, 


\title{
Editorial Comment
}

\section{Retinal microvascular diameters: normative data and their use in clinical hypertension}

\author{
Alfons J.H.M. Houben ${ }^{a}$, Tos T.J.M. Berendschot ${ }^{b}$, and Guido Grassi ${ }^{c, d}$
}

See original paper on page 1635

$\mathrm{M}$ icrovascular dysfunction has been recognized as a crucial pathway in the (early) development and progression of cardiovascular and metabolic disease [1-6]. In addition, microvascular dysfunction has been shown to be associated with increased (cardiovascular) mortality [7]. However, in-vivo assessment of microvascular structure and function is technically demanding which limits its broad applicability in observational studies and clinical trials. One exception in this respect is imaging of the retinal microcirculation. Since the early 1920 s, fundus photography has played a prominent role in diagnosing eye diseases, and because of the widespread availability of this technique it has been applied in many mechanistic and epidemiological studies.

Retinal microvascular diameters appear to be relevant, valid, and consistent markers of microvascular function. Many studies in different cohorts have consistently shown that both current and past higher arterial blood pressure (BP) is associated with reduced arteriolar diameters [8-12]. This BP-related arteriolar narrowing seems to be reversible. Antonio et al. [13] measured retinal arteriolar and venular diameters in 189 hypertensive patients before and after 6 months of antihypertensive treatment. The average arteriolar-to-venular diameter ratio increased significantly following 6 months of treatment, which was because of an increase in arteriolar diameter. Hughes et al. [14] compared the effects of 12 months BP lowering with amlodipine versus lisinopril on retinal arteriolar diameters in 25 untreated hypertensive study participants. Both treatments resulted in similar BP reduction and also in comparable reversal of arteriolar narrowing. Apart from antihypertensive treatment, also lifestyle factors may contribute to reduce unfavorable changes in retinal microvascular diameters. In an Australian cohort $(n=2683)$, the frequency

\footnotetext{
Journal of Hypertension 2017, 35:1573-1574

aDepartment of Internal Medicine, CARIM School for Cardiovascular Diseases, bUniversity Eye Clinic Maastricht, Maastricht University Medical Center, Maastricht University, Maastricht, the Netherlands, 'Clinica Medica, University of Milano-Bicocca and IIRCCS Multimedica, Sesto san Giovanni, Milan, Italy

Correspondence to Alfons J.H.M. Houben, Department of Internal Medicine, CARIM School for Cardiovascular Diseases, Maastricht University Medical Center, Maastricht, the Netherlands. E-mail: b.houben@maastrichtuniversity.nl

J Hypertens 35:1573-1574 Copyright (C) 2017 Wolters Kluwer Health, Inc. All rights reserved.

DOI:10.1097/HJH.0000000000001421
}

of fish consumption, evaluated with a questionnaire, was associated with retinal arteriolar/venular diameters [15]. It was shown that, particularly in hypertensive study participants, a higher frequency of fish consumption was associated with narrower arterioles and wider venules. Also exercise training can be used to improve retinal microvascular diameters, as was shown by Hanssen et al. [16]. They showed that following a 10 -week exercise training program, arteriolar narrowing improved in obese study participants. Finally, arteriolar narrowing may not only be an adaptive response to higher $\mathrm{BP}$, but also predict and possibly contribute to the development of hypertension [6]. As was shown in a recent meta-analysis by the Meta-Eye Study Group [17], both narrower arterioles and wider venules were independently associated with an increased risk of hypertension.

Based on the above, retinal microvascular diameters seem to be promising variables for individual risk prediction and/or an intermediate endpoint in the evaluation of antihypertensive treatment. An important requisite for this is normal reference values of retinal arteriolar and venular diameters. In the current issue of the Journal of Hypertension, Ponto et al. [18] present age and sex-specific nomograms of retinal microvascular diameters based on crosssectional data from 4309 individuals of the Gutenberg Health Study. They calculated normative data and reference values of retinal arteriolar diameters (Central Retinal Arteriolar Equivalent), venular diameters (Central Retinal Venular Equivalent), and arteriolar-to-venular diameter ratios in a subset of 890 individuals (20.6\%) who were defined as 'cardiovascular healthy', meaning absence of any of the following cardiovascular risk factor or condition: systemic hypertension, diabetes, smoking, dyslipidemia, obesity, peripheral arterial occlusive disease, heart failure, history or family history of stroke or myocardial infarction. Unfortunately, demographics and clinical characteristics were presented for the total cohort only, not for the "cardiovascular healthy' subset. In the total cohort $(n=4309), 50.2 \%$ were men and mean age was $54.8 \pm 10.8$ years. This is the first study to provide such normative data, applicable to this population. Additional studies are required to obtain more normative data for other populations and different disease groups. Some limitations of the present data are, as pointed out by the authors, the wide variability in retinal vessel parameters between individuals, a broad zone of overlap 
between different groups, and large reference ranges. Hence, the estimation of cut-off values for individuals at risk is difficult to assess. One aspect that may contribute importantly to this wide variation is that the authors have chosen to represent diameters as vessel equivalents instead of actual $\mu \mathrm{m}$. The actual vessel dimension in micrometres at the retinal plane has to be calculated using a magnification factor based on axial length and refractive error [19]. Axial length and refractive errors differ greatly between study participants, and the change in magnification from myopia to hyperopia ranges from -25 to $18 \%$ [20]. To determine vessel widths accurately in individual eyes, it is therefore essential to correct the magnification of the image captured by the fundus camera on an individual basis.

Data reported in the paper by Ponto et al. [18] have an immediate clinical impact. Indeed they provide reference values for retinal vascular parameters in healthy study participants, to which comparison of data obtained in different studies and population can be done. Static and dynamic imaging of the retinal microcirculation clearly has added valuable insight into (patho)physiological processes involved in microvascular (dys)function in cardiometabolic diseases. However, to use these techniques for individual risk stratification and evaluation of treatment efficiency, additional technical improvements and standardizations in both image acquisition and, preferably, fully automated analyses are required.

\section{AGKNOWLEDGEMENTS}

\section{Conflicts of interest}

There are no conflicts of interest.

\section{REFERENCES}

1. Chew SK, Xie J, Wang JJ. Retinal arteriolar diameter and the prevalence and incidence of hypertension: a systematic review and meta-analysis of their association. Curr Hypertens Rep 2012; 14:144-151.

2. Wong TY, Klein R, Sharrett AR, Duncan BB, Couper DJ, Tielsch JM, et al. Retinal arteriolar narrowing and risk of coronary heart disease in men and women. The Atherosclerosis Risk in Communities Study. JAMA 2002; 287:1153-1159.

3. Lee JF, Barrett-O'Keefe Z, Garten RS, Nelson AD, Ryan JJ, Nativi JN, et al. Evidence of microvascular dysfunction in heart failure with preserved ejection fraction. Heart 2016; 102:278-284.
4. Tibirica E, Souza EG, De Lorenzo A, Oliveira GM. Reduced systemic microvascular density and reactivity in individuals with early onset coronary artery disease. Microvasc Res 2015; 97:105-108.

5. Wong TY, Klein R, Couper DJ, Cooper LS, Shahar E, Hubbard LD, et al. Retinal microvascular abnormalities and incident stroke: the Atherosclerosis Risk in Communities Study. Lancet 2001; 358:1134-1140.

6. Karaca Ü, Schram MT, Houben AJ, Muris DM, Stehouwer CD. Microvascular dysfunction as a link between obesity, insulin resistance and hypertension. Diabetes Res Clin Pract 2014; 103:382-387.

7. Mutlu U, Ikram MK, Wolters FJ, Hofman A, Klaver CC, Ikram MA. Retinal microvasculature is associated with long-term survival in the general adult Dutch population. Hypertension 2016; 67:281-287.

8. Leung H, Wang JJ, Rochtchina E, Wong TY, Klein R, Mitchell P. Impact of current and past blood pressure on retinal arteriolar diameter in an older population. J Hypertens 2009; 22:1543-1549.

9. Sharrett AR, Hubbard LD, Cooper LS, Sorlie PD, Brothers RJ, Nieto FJ, et al. Retinal arteriolar diameters and elevated blood pressure: the Atherosclerosis Risk in Communities Study. Am J Epidemiol 1999; 150: 263-270.

10. Wang JJ, Mitchell P, Leung H, Rochtchina E, Wong TY, Klein R. Hypertensive retinal vessel wall signs in a general older population: the Blue Mountains Eye Study. Hypertension 2003; 42:534-541.

11. Mitchell P, Cheung N, de Haseth K, Taylor B, Rochtchina E, Islam FM, et al. Blood pressure and retinal arteriolar narrowing in children. Hypertension 2007; 49:1156-1162.

12. Murgan I, Beyer S, Kotliar KE, Weber L, Bechtold-Dalla Pozza S, Dalla Pozza R, et al. Arterial and retinal vascular changes in hypertensive and prehypertensive adolescents. Am J Hypertens 2013; 26:400-408.

13. Antonio PR, Marta PS, Luís DD, Antonio DP, Manuel ST, Rafael MS, et al. Factors associated with changes in retinal microcirculation after antihypertensive treatment. J Hum Hypertens 2014; 28:310-315.

14. Hughes AD, Stanton AV, Jabbar AS, Chapman N, Martinez-Perez ME, McG Thom SA. Effect of antihypertensive treatment on retinal microvascular changes in hypertension. J Hypertens 2008; 26:1703-1707.

15. Kaushik S, Wang JJ, Flood V, Liew G, Smith W, Mitchell P. Frequency of fish consumption, retinal microvascular signs and vascular mortality. Microcirculation 2008; 15:27-36.

16. Hanssen H, Nickel T, Drexel V, Hertel G, Emslander I, Sisic Z, et al. Exercise-induced alterations of retinal vessel diameters and cardiovascular risk reduction in obesity. Atherosclerosis 2011; 216:433-439.

17. Ding J, Wai KL, McGeechan K, Ikram MK, Kawasaki R, Xie J, et al. MetaEye Study Group: retinal vascular caliber and the development of hypertension: a meta-analysis of individual participant data. J Hypertens 2014; 32:207-215.

18. Ponto KA, Werner DJ, Wiedemer L, Laubert-Reh D, Schuster AK, Nickels S, et al. Retinal vessel metrics: normative data and their use in systemic hypertension: results from the Gutenberg Health Study. J Hypertens 2017; 35:1635-1645.

19. Patton N, Aslam TM, MacGillivray T, Deary IJ, Dhillon B, Eikelboom $\mathrm{RH}$, et al. Constable Retinal image analysis: concepts, applications and potential. Prog Retin Eye Res 2006; 25:99-127.

20. Arnold JV, Gates JW, Taylor KM. Possible errors in the measurement of retinal lesions. Invest Ophthalmol Vis Sci 1993; 34:2576-2580. 